\title{
PERAN ACHIEVEMENT GOAL ORIENTATION DAN NORMA SUBJEKTIF DALAM MEMPREDIKSI KECURANGAN AKADEMIK SELAMA BELAJAR DARI RUMAH
}

\author{
Azka Amalina dan Eva Septiana \\ Fakultas Psikologi, Universitas Indonesia \\ Jalan Lkr. Kampus Raya, Jalan Mawar No. 538, Kecamatan Beji, Kota Depok, 16424 \\ Email: azka.amalina91@ui.ac.id
}

\begin{abstract}
ABSTRAK
Sejak adanya pandemi COVID-19, Kementerian Pendidikan dan Kebudayaan Indonesia menginstruksikan sekolah untuk menerapkan sistem Belajar Dari Rumah (BDR). Pembelajaran dan penilaian yang tidak dilakukan secara langsung tidak terlepas dari adanya isu kecurangan akademik. Penelitian ini bertujuan untuk melihat peran dari faktor kecurangan akademik, yaitu achievement goal orientation dan norma subjektif dalam memprediksi kecurangan akademik yang dilakukan peserta didik jenjang pendidikan menengah atas selama BDR. Partisipan pada penelitian ini terdiri dari 183 orang peserta didik jenjang pendidikan menengah atas yang melaksanakan BDR. Partisipan dipilih dengan convenience sampling dan snowball sampling. Alat ukur yang digunakan adalah Academic Dishonesty Scale, Achievement Goal Questionnaire, dan bagian Norma Subjektif dari The Perception and Attitudes toward Cheating among Engineering Students Survey, version 2 yang telah diadaptasi ke dalam Bahasa Indonesia serta disesuaikan dengan pembelajaran BDR dan populasi penelitian. Hasil penelitian menunjukkan bahwa tipe achievement goal orientation dan norma subjektif secara bersama-sama signifikan dalam memprediksi kecurangan akademik, namun jika dilihat lebih lanjut, hanya norma subjektif yang secara signifikan memprediksi kecurangan akademik. Sementara itu, tipe achievement goal orientation tidak memiliki peran yang signifikan dalam memprediksi kecurangan akademik. Hal ini mengindikasikan bahwa dalam melakukan kecurangan akademik, siswa jenjang pendidikan menengah atas lebih dipengaruhi oleh persepsinya terhadap teman sebaya dibandingkan dengan tujuan belajarnya. Oleh karena itu, dalam melakukan penanganan dan pencegahan terkait kecurangan akademik selama BDR, perlu dilakukan intervensi yang bersifat sistemik dibandingkan dengan intervensi individual.
\end{abstract}

Kata kunci: kecurangan akademik; orientasi berprestasi; norma subjektif

\section{THE ROLE OF ACHIEVEMENT GOAL ORIENTATIONS AND SUBJECTIVE NORMS TO PREDICT ACADEMIC DISHONESTY DURING LEARNING FROM HOME}

\begin{abstract}
Due to COVID-19, the Indonesian Ministry of Education and Culture instructed all schools to implement School from Home (SFH). The learning and assessment process that cannot be done face-to-face leads to academic dishonesty issues. This study investigated the role of academic dishonesty factors, named achievement goal orientation and subjective norms, to predict academic dishonesty among high school students during SFH. Participants of this study were high school students $(N=183)$ who do SFH. Participants were chosen by convenience sampling and snowball sampling. The instruments used in this study were the Academic Dishonesty Scale, the Achievement Goal Questionnaire, and the Subjective Norms part of the Perception and Attitudes toward Cheating among Engineering Students Survey version 2, adapted into Indonesian language, SFH setting, and the research population. This study showed that achievement goal orientation and subjective norms altogether significantly predict academic dishonesty. However, only subjective norms have a significant role in predicting academic dishonesty. At the same time, achievement goal orientation has no significant role in predicting academic dishonesty. It infers that the high school students were more affected by their perception of their peers than the personal goal regarding academic dishonesty. This study implies that the intervention of academic dishonesty during SFH should be done through systemic intervention instead of individual intervention.
\end{abstract}

Keywords: academic dishonesty; achievement goal orientation; subjective norms 


\section{PENDAHULUAN}

Sejak sekitar akhir tahun 2019, hampir seluruh negara di dunia menghadapi pandemi COVID-19. Adanya pandemi COVID-19 berdampak pada berbagai aspek kehidupan, termasuk pendidikan. Sejak pertengahan Maret 2020, Menteri Pendidikan mengeluarkan Surat Edaran yang berisi imbauan bagi satuan pendidikan untuk melakukan pembelajaran dengan metode Pembelajaran Jarak Jauh (PJJ) dengan program yang diistilahkan sebagai Belajar Dari Rumah (BDR) (Kementerian Pendidikan dan Kebudayaan, 2020). Menurut Mustafa (2020), karakteristik yang membedakan pembelajaran tatap muka dan BDR adalah tidak adanya kontak langsung antara guru dan peserta didik sehingga terjadi perubahan pada pola pembelajaran dan penilaian peserta didik. Adanya perubahan pada penilaian, yaitu ketikapenilaian tidak dapat dilakukan secara langsung memiliki kaitan dengan isu kecurangan akademik (McCabe dkk., 2012). Kecurangan akademik sendiri merupakan tingkah laku tidak jujur untuk mendapatkan nilai yang baik atau lulus dalam ujian (Blachnio, 2019). Bentuk-bentuk kecurangan akademik secara umum adalah menyontek ketika ujian, plagiarisme, menerima bantuan yang tidak sah, mempersiapkan kecurangan, pemalsuan, dan bohong terkait tugas akademik (Bashir \& Bala, 2018).

Sebelum adanya pandemi, kecurangan akademik sudah menjadi suatu masalah dalam pembelajaran. Begitu pula ketika BDR. Berdasarkan survei awal yang dilakukan oleh peneliti kepada 21 peserta didik jenjang pendidikan menengah atas di Depok dan Jakarta dengan teknik pemilihan partispan secara random sampling dan juga informasi dari pemberitaan di media, diketahui bahwa kecurangan akademik juga terjadi dalam BDR dan bahkan dianggap lebih banyak terjadi dibandingkan dengan ketika pembelajaran tatap muka. Berdasarkan hasil survei dan pemberitaan di media, bentuk kecurangan akademik yang kerap dilakukan ketika BDR adalah menggunakan sesuatu yang dilarang dalam mengerjakan ujian dan tugas seperti mencari jawaban di mesin pencarian atau membuka buku ketika ujian, menyalin jawaban teman, menyalin artikel di internet, dan menggunakan media sosial untuk saling membagi jawaban ketika ujian (Greduasia, 2020).

Kecurangan akademik dapat berdampak bagi peserta didik maupun institusi pendidikan. Dampak kecurangan akademik pada peserta didik di antaranya adalah dapat menurunkan self-esteem, menghambat perkembangan intelektual dan psikososial, menghambat perkembangan nilai positif seperti integritas, membuat peserta didik cenderung akan menormalisasi tingkah laku tidak etis, dan membuat peserta didik memiliki persepsi yang salah mengenai kemampuannya (Boehm dkk., 2009 dalam Krou dkk., 2020; Diego, 2017; Guerrero-Dib dkk., 2020; Krou dkk., 2020; Munoz \& Mackay, 2019). Bagi institusi, dampak kecurangan akademik adalah dapat menurunkan tingkat kepercayaan terhadap insitusi karena nilai yang didapatkan siswa tidak menggambarkan kemampuannya (Munoz \& Mackay, 2019; Yu dkk. 2016 dalam Krou dkk., 2020).

Dari keseluruhan jenjang pendidikan, diketahui bahwa kecurangan akademik lebih rentan dilakukan oleh peserta didik jenjang pendidikan menengah atas dibandingkan dengan jenjang pendidikan tinggi ataupun jenjang pendidikan menengah pertama (Anderman \& Midgley, 2004; Jensen dkk., 2002; Kaufman, 2008). Oleh karenanya, penelitian ini akan berfokus pada kecurangan akademik yang dilakukan oleh peserta didik jenjang pendidikan menengah atas yang melakukan BDR. Jenjang pendidikan menengah atas dalam penelitian ini meliputi Sekolah Menengah Atas (SMA), Sekolah Menengah Kejuruan (SMK), dan Madrasah Aliyah (MA).

Adanya dampak buruk bagi perkembangan peserta didik ke depannya, membuat penanganan terhadap kecurangan akademik menjadi diperlukan. Oleh karena itu, perlu diketahui faktor-faktor yang berpengaruh terhadap kecurangan akademik. Menurut McCabe dkk. (2012), kecurangan akademik secara umum dipengaruhi oleh faktor individual dan faktor kontekstual. Faktor individual yang berpengaruh terhadap kecurangan akademik di antaranya adalah faktor demografis seperti gender, usia, dan status ekonomi, serta faktor individu lainnya seperti kepribadian, motivasi dan tujuan berprestasi, academic self-efficacy, impulsivitas, dll. (McCabe, dkk, 2012; Yu dkk., 2016; Peled dkk., 2019; Krou dkk., 2020). Sementara itu, beberapa faktor kontekstual yang dapat memengaruhi kecurangan akademik di antaranya adalah pengaruh teman, penghargaan dan hukuman, faktor kelas, dan norma subjektif (McCabe dkk., 2012; Lonsdale; 2016; Imran \& Nordin, 2013; Ives \& Giukin, 2019).

Beberapa faktor individu yang berpengaruh dalam kecurangan akademik di antaranya merupakan sesuatu yang cenderung menetap dan sulit diubah sehingga kurang tepat digunakan untuk mencegah atau 
menangani kecurangan akademik (Krou dkk., 2020). Di sisi lain, Krou dkk. (2020) juga menjelaskan bahwa faktor individu yang terkait dengan motivasi berprestasi akan dapat lebih mudah untuk diubah dan lebih memungkinkan untuk diintervensi dalam mencegah dan menangani kecurangan akademik. Salah satu topik bahasan yang termasuk dalam motivasi berprestasi dan dalam penelitian sebelumnya banyak dikaitkan dengan kecurangan akademik adalah achievement goal orientation (Anderman \& Koenka, 2017; Daumiller \& Janke, 2019; Apostolou, 2015; Yang dkk., 2013).

Achievement goal orientation merupakan tujuan kognitif yang dinamis dan berfokus pada standar yang digunakan untuk mengevaluasi tujuan tersebut (Elliot dan Murayama, 2008). Dalam bidang pendidikan, tujuan di sini biasanya diasosiasikan dengan tujuan dalam tugas akademik (Pintrich, 2000). Berdasarkan hal tersebut, dapat disimpulkan bahwa achievement goal orientation pada peserta didik merupakan tujuan peserta didik untuk mencapai prestasi dalam tugas akademik dan bagaimana siswa akan mengevaluasi tujuannya tersebut (Pintrich, 2000; Elliot \& Murayama, 2008). Secara umum, achievement goal orientation dibedakan menjadi mastery dan performance (Elliot \& McGregor, 2001). Mastery merupakan tujuan yang standar evaluasinya adalah mengembangkan kemampuan diri dalam menyelesaikan materi, sementara performance merupakan tujuan yang standar evaluasinya adalah bagaimana seseorang menunjukkan kemampuannya dibandingkan dengan orang lain. Elliot dan McGregor (2001) serta Pintrich (2000) menambahkan adanya valensi dari masing-masing tipe achievement goal orientation. Valensi dalam tipe achievement goal orientation melihat apakah seseorang bertujuan untuk mendekati kesuksesan (approach) atau menghindari kegagalan (avoidance). Hal ini menghasilkan model konseptual $2 \times 2$ dalam menjelaskan tipe achievement goal orientation; yaitu mastery-approach, mastery-avoidance, performance-approach, dan performance-avoidance. Dalam belajar, peserta didik dapat memiliki tujuan untuk memahami materi pembelajaran yang diberikan (mastery-approach), menghindari ketidakpahaman materi belajar (mastery-avoidance), ingin menunjukkan kemampuannya lebih baik dari teman-temannya (performance-approach), ataupun untuk tidak menunjukkan kemampuannya lebih buruk dari teman-temannya (performance-avoidance) (Anderman \& Koenka, 2017).

Secara konseptual, jika tujuan belajar peserta didik benar-benar untuk menguasai pembelajaran, maka kecurangan akademik bukanlah strategi yang akan mereka gunakan untuk mencapai tujuan tersebut karena tidak akan membantu mereka untuk menguasai pembelajaran (Apostolou, 2015). Di sisi lain, ketika tujuan belajar peserta didik adalah untuk menunjukkan performa belajar lebih baik atau tidak lebih buruk dari teman-temannya, maka kecurangan akademik dapat menjadi salah satu jalan pintas untuk mencapai tujuan tersebut (Apostolou, 2015). Menurut Anderman dan Koenka (2017), tidak menutup kemungkinan pula peserta didik mengadopsi lebih dari satu tujuan dalam belajarnya, sepeti seseorang bisa ingin dapat menguasai materi pelajaran dan juga ingin menunjukkan bahwa ia tidak lebih buruk dibandingkan dengan teman-temannya.

Beberapa penelitian telah mencoba membuktikan hubungan antara tipe achievement goal orientation dan kecurangan akademik. Meskipun demikian, hasil dari penelitian terdahulu masih belum konsisten, kecuali pada tipe mastery-approach (Apostolou, 2015; Huang dkk., 2015; Krou dkk., 2020; Van Yperen dkk., 2011; Yang dkk., 2013). Tipe mastery-approach menunjukkan hubungan yang negatif dengan kecurangan akademik, yaitu ketika peserta didik makin bertujuan untuk memahami materi, ia tidak akan melakukan kecurangan akademik. Pada tipe mastery-avoidance, performance-approach, dan performance-aovidance, belum terlihat adanya hubungan yang konsisten. Oleh karenanya, menurut Apostolou (2015) dan Yang dkk. (2013), ketidakkonsistenan ini perlu diteliti lebih lanjut.

Menurut McCabe dkk. (2012), dalam memprediksi kecurangan akademik, faktor individu merupakan hal yang penting untuk diketahui, namun tidak cukup kuat untuk memprediksi kecurangan akademik sehingga perlu juga untuk mempertimbangkan faktor kontekstual. McCabe dkk. (2012) menyatakan bahwa salah satu faktor kontekstual yang berpengaruh kuat terhadap kecurangan akademik adalah teman sebaya. Persepsi seseorang mengenai apakah ia boleh melakukan tingkah laku tertentu, yang dalam penelitian ini adalah kecurangan akademik, atau tidak menurut orang-orang yang penting baginya disebut dengan norma subjektif (Harding dkk., 2007). Norma subjektif merupakan hal yang berbeda dengan norma sosial, dimana norma sosial merupakan aturan mengenai apakah suatu tingkah laku dianggap sesuai, sedangkan norma subjektif merupakan persepsi seseorang mengenai norma sosial 
yang berlaku (Neighbors dkk., 2013). Menurut Neighbors dkk. (2013), persepsi seseorang, yaitu norma subjektif, akan lebih memengaruhi dirinya dibandingkan dengan realita yang ada, yaitu norma sosial.

Seperti yang telah dipaparkan, norma subjektif merupakan persepsi seseorang terhadap pandangan kelompok referensi terkait tingkah laku tertentu, yang dalam hal ini adalah kecurangan akademik. Jika dikaitkan dengan karakteristik peserta didik jenjang pendidikan menengah atas, yang tergolong dalam tahap perkembangan remaja, mereka cenderung menjadikan temannya sebagai acuan moral (Papalia \& Martorell, 2014). Hal ini membuat teman sebaya menjadi kelompok referensi yang penting dalam norma subjektif terkait kecurangan akademik pada peserta didik jenjang pendidikan menengah atas. Ketika seseorang mempersepsi bahwa kecurangan akademik boleh dilakukan, ia juga akan cenderung melakukan kecurangan akademik, begitu pula sebaliknya (Imran \& Nordin, 2013; Kam dkk., 2018; Lonsdale; 2016). Dengan metode pembelajaran jarak jauh yang dilakukan selama BDR ini, dimana interaksi antarpeserta didik lebih terbatas, peneliti ingin melihat bagaimana peran norma subjektif dalam memprediksi kecurangan akademik pada peserta didik.

Berdasarkan penjelasan yang telah dipaparkan, tipe achievement goal orientation dan norma subjektif dapat menjadi faktor-faktor yang dapat memprediksi kecurangan akademik pada peserta didik selama menjalani BDR dan mungkin dapat dijadikan penanganan dan pencegahan kecurangan akademik. Meskipun demikian, berdasarkan penelitian-penelitian yang telah dilakukan sebelumnya, masih terdapat hubungan yang belum konsisten antarvariabel. Selain itu, penelitian sebelumnya dilakukan dalam konteks pembelajaran tatap muka. Oleh karena itu, dalam penelitian ini, peneliti ingin melihat peran dari tipe achievement goal orientation dan norma subjektif dalam memprediksi kecurangan akademik peserta didik jenjang pendidikan menengah atas selama menjalani BDR. Hipotesis yang diajukan adalah:

$\mathrm{Ha}_{1}$ : Terdapat peran tipe achievement goal orientation dan norma subjektif secara bersama-sama dalam memprediksi kecurangan akademik peserta didik jenjang pendidikan menengah atas selama menjalani BDR.

$\mathrm{Ha}_{1.1}$ : Mastery-approach memprediksi kecurangan akademik peserta didik jenjang pendidikan menengah atas selama menjalani BDR.

Ha $_{1.2}$ : Mastery-avoidance memprediksi kecurangan akademik peserta didik jenjang pendidikan menengah atas selama menjalani BDR.

Ha $_{1.3}:$ Performance-approach memprediksi kecurangan akademik peserta didik jenjang pendidikan menengah atas selama menjalani BDR.

$\mathrm{Ha}_{1.4}$ : Performance-avoidance memprediksi kecurangan akademik peserta didik jenjang pendidikan menengah atas selama menjalani BDR.

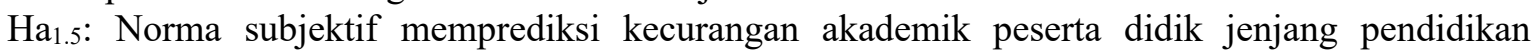
menengah atas selama menjalani BDR.

\section{METODE}

Penelitian ini menggunakan pendekatan kuantitatif noneksperimental, dimana peneliti mengukur variabel menggunakan alat ukur untuk mendapatkan skor berupa nilai angka yang kemudian dianalisis lebih lanjut. Peneliti juga tidak melakukan manipulasi pada variabel penelitian. Penelitian ini tergolong sebagai penelitian korelasional karena peneliti bertujuan untuk mengidentifikasi pola hubungan antarvariabel dan kekuatan hubungannya. Variabel terikat dalam penelitian ini adalah kecurangan akademik dan variabel prediktor adalah keempat tipe achievement goal orientation dan norma subjektif.

Partisipan dalam penelitian ini adalah peserta didik Sekolah Menengah Atas (SMA), Sekolah Menengah Kejuruan (SMK), maupun Madrasah Aliyah (MA), yang berada pada kelas X - XII di Indonesia yang bersekolah di sekolah formal, baik sekolah negeri maupun sekolah swasta dan melaksanakan Belajar Jarak Jauh (BDR) selama pandemi COVID-19. Pemilihan sampel dilakukan dengan metode convenience sampling dan snowball sampling dengan menyebar pengumuman dibutuhkannya partisipan penelitian melalui media sosial dan sampel didapatkan berdasarkan ketersediaan dan kesediaan partisipan, serta dengan meminta peserta didik jenjang pendidikan menengah atas menyebarkan informasi penelitian kepada teman-temannya. Teknik pemilihan sampel ini juga dirasa paling sesuai dengan metode pengambilan data yang dilakukan secara daring. Sebagai kontrol, akan ditambahkan kriteria berupa durasi pelaksanaan BDR, yaitu sejak Juli 2020 sampai dengan penelitian 
dilakukan pada April 2021. Hal ini dilakukan karena mengingat adanya beberapa daerah di Indonesia yang telah mengizinkan pembelajaran tatap muka bergilir yang dapat berdampak pada pola kecurangan akademik yang mungkin akan berubah dengan setting pembelajaran yang juga telah berubah. Target jumlah partisipan penelitian adalah 138 partisipan. Penentuan jumlah partisipan penelitian ditentukan dengan $G^{*}$ Power. Berdasarkan hasil penghitungan $G^{*}$ Power, untuk mendapatkan effect size .15 dengan jumlah variabel prediktor sebanyak lima variabel (mastery-approach, mastery-avoidance, performanceapproach, performance-avoidance, dan norma subjektif) dibutuhkan minimal 138 partisipan.

Kecurangan akademik diukur dengan Academic Dishonesty Scale (ADS) yang dikonstruksi oleh Bashir dan Bala (2018) dan telah diadaptasi oleh peneliti serta item-nya disesuaikan dengan pembelajaran BDR atas seizin pembuat alat ukur. Semakin besar skor yang didapatkan partisipan, menujukkan bahwa ia mempersepsi dirinya lebih sering melakukan kecurangan akademik. Tipe Achievemement Goal Orientation diukur dengan Achievement Goal Questionnaire-Revised (AGQ-R) yang dikembangkan oleh Elliot dan Murayama (2008) dan telah diadaptasi oleh Rodliya (2018) untuk peserta didik jenjang pendidikan menengah atas. Akan didapatkan skor dari masing-masing tipe Achievement Goal Orientation. Semakin tinggi skor partisipan pada suatu tipe, menunjukkan ia semakin mengadopsi tipe tersebut dalam pembelajarannya. Norma subjektif diukur dengan The Perception and Attitudes toward Cheating among Engineering Students Survey, version 2 (PACES-2) bagian Norma Subjektif yang dikonstruksi oleh Harding dkk. (2007) dan telah diadaptasi oleh peneliti dengan seizin pembuat alat ukur. Semakin tinggi skor yang didapatkan partisipan, menunjukkan bahwa ia menganggap temannya lebih menyetujui kecurangan akademik. Uji coba alat ukur dilakukan kepada 55 peserta didik jenjang pendidikan menengah atas yang melakukan BDR. Berikut adalah koefisien Cronbach's alpha dari masing-masing alat ukur: $\mathrm{ADS}=0,84$, Mastery-Approach AGQ-R $=0,85$, Mastery-Avoidance AGQR $=0,61$, PerformanceApproach AGQ-R = 0,71, Performance-Avoidance AGQ-R = 0,81, dan PACES-2 Bagian Norma Subjektif $=0,92$. Menurut Ursachi dkk. (2015), nilai Cronbach's Alpha di atas 0,6 dapat dikatakan diterima. Berdasarkan hal ini dapat disimpulkan bahwa alat ukur yang telah diadaptasi tersebut memiliki konsistensi internal yang dapat diterima.

Penelitian diawali dengan studi literatur terkait fenomena dan studi pendahuluan untuk lebih memahami fenomena. Studi pendahuluan dilakukan dengan survei kepada 21 peserta didik jenjang pendidikan menengah atas di Depok dan Jakarta mengenai kecurangan akademik selama BDR. Selanjutnya, peneliti menentukan alat ukur yang digunakan dalam penelitian, meminta izin penggunaan kepada pembuat alat ukur, dan melakukan adaptasi dan modifikasi alat ukur sesuai dengan populasi dan konteks penelitian. Peneliti lalu menyusun proposal penelitian dan mengajukan kaji etik penelitian kepada Komite Etika Penelitian Fakultas Psikologi Universitas Indonesia. Setelah mendapatkan surat yang menyatakan bahwa penelitian ini lolos kaji etik dengan nomor surat 982/FPsi.KomiteEtik/PDP.04.00/2020, peneliti melakukan uji coba alat ukur.

Pengambilan data dilakukan pada tanggal 15 April - 7 Mei 2021 secara daring dengan mempertimbangkan kondisi pandemi di Indonesia. Untuk memperoleh partisipan, peneliti membuatposter dan pengumuman yang kemudian disebarluaskan melalui media sosial dan media komunikasi kepada peserta didik jenjang pendidikan menengah atas di Indonesia. Proses pengambilan data dilakukan melalui Google Form. Konten dalam Google Form tersebut berisi gambaran umum penelitian, informed consent, dan kuesioner. Kuesioner terdiri dari empat bagian, yaitu data diri, AGQ-R, PACES-2 bagian Norma Subjektif, dan ADS. Pengolahan data dilakukan dengan uji korelasi untuk melihat keterkaitan antarvariabel dan uji regresi linier berganda dengan kecurangan akademik sebagai variabel terikat dan keempat tipe achievement goal orientation serta norma subjektif sebagai variabel prediktor.

\section{HASIL DAN PEMBAHASAN}

Setelah melakukan pengambilan data, didapatkan data berjumlah 249 dari peserta didik jenjang pendidikan menengah atas di Indonesia yang melaksanakan BDR. Meskipun demikian, setelah dilakukan screening, terdapat 58 data partisipan yang tidak sesuai dengan kriteria. Selain itu, terdapat pula delapan data outlier yang tidak diikutsertakan dalam penelitian ini. Oleh karena itu, setelah dikurangi data yang tidak sesuai kriteria dan data outlier, total data partisipan berjumlah 183. Berikut adalah gambaran persebaran data demografis partisipan: 
Tabel 1. Karakteristik Partisipan

\begin{tabular}{lcc}
\hline Karakteristik & $\boldsymbol{n}$ & $\mathbf{\%}$ \\
\hline Jenis Kelamin & 129 & 70.5 \\
Perempuan & 54 & 29.5 \\
\hline Laki-laki & & \\
\hline Kelas & 78 & 42.6 \\
X & 83 & 45.4 \\
XII & 22 & 12.0 \\
\hline Usia & & \\
15 tahun & 25 & 13.7 \\
16 tahun & 84 & 45.9 \\
17 tahun & 60 & 32.8 \\
18 tahun & 14 & 7.7 \\
\hline Jenis Sekolah & & \\
Sekolah Menengah Atas (SMA) & 146 & 79,8 \\
Sekolah Menengah Kejuruan (SMK) & 18 & 9,8 \\
Madrasah Aliyah (MA) & 19 & 10,4 \\
\hline Asal Pulau & & \\
Sumatera & 7 & 3.8 \\
Kalimantan & 32 & 17.5 \\
Jawa & 140 & 76.5 \\
Sulawesi & 3 & 1.6 \\
Bali dan Nusa Tenggara & 1 & 0.5 \\
Maluku dan Papua & 0 & 0 \\
\hline & & \\
\hline
\end{tabular}

Sebagian besar dari partisipan penelitian berjenis kelamin perempuan (70.5\%) Berdasarkan usia, dapat disimpulkan bahwa seluruh partisipan berada dalam tahap perkembangan remaja. Jika dilihat dari tingkat kelasnya, partisipan penelitian lebih banyak yang sedang duduk di kelas X (42.6\%) dan kelas XI (45.4\%). Hal ini terlihat berkaitan dengan kegiatan belajar kelas XII yang ketika itu sudah cenderung lebih sedikit dibandingkan dengan kelas X dan XI karena telah menyelesaikan ujian. Berdasarkan jenis sekolah pada jenjang pendidikan menengah atas di Indonesia, dapat dilihat bahwa partisipan penelitian berasal dari jenis sekolah yang berbeda. Mayoritas dari partisipan penelitian bersekolah di Sekolah Menengah Atas (79.9\%).

Berdasarkan domisilinya, mayoritas partisipan penelitian berdomisili di Pulau Jawa (76.5\%). Selain itu, tidak terdapat partisipan penelitian yang berasal dari Kepulauan Maluku dan Pulau Papua. Tidak meratanya persebaran domisili partisipan disebabkan oleh pengumuman penelitian yang lebih banyak tersebar di Pulau Jawa dibandingkan di daerah lain. Di samping itu, pada beberapa daerah di luar Pulau Jawa, seperti pada sejumlah daerah di Pulau Sulawesi, sudah terdapat sekolah-sekolah yang mengadakan pembelajaran tatap muka serta pembelajaran dengan menggabungkan metode tatap muka dan juga BDR.

Sebelum melakukan uji hipotesis, peneliti lebih dahulu melakukan uji korelasi untuk melihat hubungan antarvariabel penelitian. Berdasarkan hasil uji korelasi, diketahui bahwa kecurangan akademik memiliki korelasi yang positif signifikan dengan norma subjektif $(r=.54, p>.05)$, yang menunjukkan bahwa ketika peserta didik mempersepsi bahwa teman-temannya mendukung kecurangan akademik, ia akan makin sering melakukan kecurangan akademik tersebut. Kecurangan akademik juga memiliki korelasi yang negatif signifikan dengan mastery-approach $(r=-0.22, p<.5)$, yang menunjukkan bahwa ketika tujuan belajar peserta didik adalah lebih untuk memahami materi, ia akan lebih cenderung tidak 
melakukan kecurangan akademik. Selain itu, dapat dilihat bahwa terdapat korelasi yang signifikan antartipe achievement goal orientation.

Tabel 2. Hasil Korelasi Antarvariabel

\begin{tabular}{llllllll}
\hline & \multicolumn{1}{c}{ Variabel } & \multicolumn{1}{c}{$\mathbf{1}$} & $\mathbf{2}$ & $\mathbf{3}$ & $\mathbf{4}$ & $\mathbf{5}$ & $\mathbf{6}$ \\
\hline $\mathbf{1}$ & Kecurangan Akademik & 1 & & & & & \\
$\mathbf{2}$ & Norma Subjektif & $.54^{* *}$ & 1 & & & & \\
$\mathbf{3}$ & Mastery-Approach & $-.22^{* *}$ & $-.22^{* *}$ & 1 & & & \\
$\mathbf{4}$ & Mastery-Avoidance & -.12 & -.06 & $.35^{* *}$ & 1 & & \\
$\mathbf{5}$ & Performance-Approach & -.10 & -.01 & $.52^{* *}$ & $.35^{* *}$ & 1 & \\
$\mathbf{6}$ & Performance-Avoidance & .10 & $.16^{*}$ & $.18^{*}$ & $.46^{* *}$ & $.45^{* *}$ & 1 \\
\hline
\end{tabular}

Sebelum dilakukan uji regresi linier berganda, peneliti juga melakukan uji asumsi berupa uji multikolinearitas, heteroskedastisitas, normalitas, dan linearitas (Field, 2013). Hasil menunjukkan bahwa data partisipan penelitian memenuhi keseluruhan uji asumsi. Oleh karena itu, dapat dilakukan uji regresi linier berganda.

Berdasarkan hasil uji regresi linier berganda, diketahui bahwa keempat tipe achievement goal orientation dan norma subjektif secara bersama-sama menjelaskan proporsi varians yang signifikan dari kecurangan akademik, $R^{2}=.31, F(5.18)=15.76, p<.05$, yang menunjukkan bahwa $31 \%$ varians dari kecurangan akademik dapat diprediksi dari keempat tipe achievement goal orientation dan norma subjektif secara bersama-sama, sementara $69 \%$ sisanya dijelaskan oleh variabel lain.

Tabel 3. Hasil Uji Multiple Regression Achievement Goal Orientation dan Norma Subjektif terhadap Kecurangan Akademik

\begin{tabular}{cccc}
\hline $\boldsymbol{R}$ & $\boldsymbol{R}^{\mathbf{2}}$ & $\boldsymbol{F}$ & Signifikansi \\
\hline .56 & .31 & 15.76 & .000 \\
\hline
\end{tabular}

Tabel 4. Koefisien Uji Multiple Regression Achievement Goal Orientation dan Norma Subjektif terhadap Kecurangan Akademik

\begin{tabular}{|c|c|c|c|c|}
\hline \multirow[t]{2}{*}{ Variabel } & \multicolumn{2}{|c|}{$\begin{array}{c}\text { Unstandardized } \\
\text { Coefficients } \\
\end{array}$} & \multirow{2}{*}{$\begin{array}{c}\text { Standardized } \\
\text { Coefficients } \\
B\end{array}$} & \multirow[t]{2}{*}{ Sig. } \\
\hline & $B$ & $\overline{S E}$ & & \\
\hline (Constant) & 29.99 & 5.09 & & .00 \\
\hline Mastery-approach & -.41 & .40 & -.08 & .28 \\
\hline Mastery-avoidance & -.34 & .30 & -.09 & .25 \\
\hline Performance-approach & -.07 & .29 & -.02 & .81 \\
\hline Performance-avoidance & .30 & .26 & .09 & .30 \\
\hline Norma Subjektif & .45 & .06 & .50 & $.00 *$ \\
\hline
\end{tabular}

Berdasarkan hasil analisis di atas, dapat dilihat bahwa hanya norma subjektif $(\beta=.50, p<.05)$ yang secara signifikan memprediksi kecurangan akademik. Sementara itu, keempat tipe achievement goal orientation tidak memprediksi kecurangan akademik secara signifikan; mastery-approach $(\beta=-.08, p>$ $0,05)$, mastery-avoidance $(\beta=-.09, p>.05)$, performance-approach $(\beta=-.020, p>.05)$, dan performance-avoidance $(\beta=.09, p>.05)$.

Berdasarkan uraian hasil penelitian di atas, berikut akan dipaparkan pembahasan dari hasil tersebut. Hasil korelasi antarvariabel yang dilakukan sebelum uji hipotesis menunjukkan bahwa masteryapproach memiliki hubungan negatif yang signifikan dengan kecurangan akademik, sementara tipe lain dari achievement goal orientation tidak berhubungan dengan kecurangan akademik. Berdasarkan hubungan tersebut, dapat dilihat bahwa semakin peserta didik mengadopsi tujuan belajar untuk dapat memahami materi, maka ia akan jarang melakukan kecurangan akademik. Hal ini karena kecurangan akademik bukanlah strategi belajar yang dapat membuat peserta didik dapat memahami materi pelajaran 
seperti tujuan belajarnya (Apostolou, 2015). Hasil korelasi antarvariabel juga menunjukkan bahwa tidak terdapat hubungan yang signifikan antara mastery-avoidance, performace-approach, dan performanceavoidance dengan kecurangan akademik.

Temuan ini juga menguatkan hasil penelitian sebelumnya mengenai hubungan antara tipe achievement goal orientation dan kecurangan akademik. Hasil review yang dilakukan Krou dkk. (2020) dari berbagai penelitian terdahulu menunjukkan bahwa terdapat hubungan negatif signifikan yang konsisten antara mastery-approach dan kecurangan akademik. Krou dkk. (2020) juga menemukan bahwa berdasarkan hasil metaanalisis, tidak terdapat hubungan antara mastery-avoidance, performanceapproach, dan performance-avoidance dengan kecurangan akademik. Tidak adanya hubungan dari ketiga tipe achievement goal orientation dengan kecurangan akademik pada metaanalisis tersebut disebabkan oleh ketidakkonsistenan hasil penelitian-penelitian sebelumnya sehingga effect size yang didapatkan menjadi kecil.

Hasil hubungan antarvariabel yang didapatkan merupakan hubungan antara satu variabel dengan satu variabel lainnya tanpa mempertimbangkan variabel lain selain keduanya. Berdasarkan hal ini, hubungan yang signifikan antara mastery-approach dan kecurangan akademik belum mempertimbangkan baik adanya peran dari tipe achievement goal orientation lainnya, maupun norma subjektif. Ketika peran dari keempat tipe achievement goal orientation dan norma subjektif dipertimbangkan secara bersamasama dalam memprediksi kecurangan akademik, diketahui bahwa hanya norma subjektif yang signifikan memprediksi kecurangan akademik, sementara mastery-approach, mastery-avoidance, performaceapproach, dan performance-avoidance tidak memprediksi kecurangan akademik.

Tidak signifikannya peran dari tipe achievement goal orientation dalam memprediksi kecurangan akademik sejalan dengan penelitian Shmeleva dan Semenova (2019) yang menemukan bahwa peran motivasi dalam memprediksi kecurangan akademik cenderung tampak lebih besar dari seharusnya. Menurut penelitian tersebut, peran motivasi dalam memprediksi kecurangan akademik tampak besar ketika peneliti tidak mempertimbangkan faktor kontekstual. Dalam penelitian ini, dibandingkan dengan besarnya peran norma subjektif yang merupakan faktor kontekstual dalam memprediksi kecurangan akademik, peran achievement goal orientation yang merupakan faktor individu menjadi kecil dan tidak signifikan. Hal ini juga mengindikasikan bahwa peserta didik jenjang pendidikan menengah atas cenderung dipengaruhi oleh persepsi mereka terhadap teman-temannya dibandingkan dengan tujuan belajar yang mereka miliki dalam tingkah laku kecurangan akademik yang mereka lakukan.

Peran dari norma subjektif dalam memprediksi kecurangan akademik adalah ketika kelompok referensi norma subjektif, yang dalam penelitian ini adalah teman-teman, lebih menyetujui kecurangan akademik, maka dapat diprediksikan bahwa seseorang akan cenderung melakukan kecurangan akademik. Peran norma subjektif dalam memprediksi kecurangan akademik pada penelitian ini konsisten dengan hasil penelitian McCabe dkk. (2012) dan Maloshonok dan Shmeleva (2019) yang juga menemukan bahwa norma subjektif memiliki hubungan yang besar terhadap kecurangan akademik. McCabe dkk. (2012) dalam penelitiannya menjelaskan bahwa mahasiswa tingkat awal lebih cenderung melakukan kecurangan akademik dibandingkan dengan mahasiswa tingkat akhir karena mahasiswa tingkat awal berada pada tahapan perkembangan moral yang lebih awal, yaitu tahap conventional. Peserta didik jenjang pendidikan menengah atas juga termasuk dalam tahapan moral conventional tersebut. Mereka cenderung ingin mempertahankan hubungan sosial dan peraturan sosial yang ada dan belum menjadikan standar benar, salah, dan keadilan sebagai pertimbangan keputusannya sehingga lebih mudah terpengaruh oleh teman-temannya (McCabe dkk., 2012; Papalia \& Martorell, 2014). Hal ini juga dapat menjadi alasan mengapa norma subjektif memiliki hubungan yang lebih besar dengan kecurangan akademik. Selain itu, diketahui bahwa pada budaya yang cenderung kolektivis, kecurangan akademik akan lebih dipengaruhi oleh norma subjektif dibandingkan dengan nilai personal (Chudzicka-Czupala dkk. dalam Dendir \& Maxwell, 2020). Hal ini juga tampak berlaku di budaya Indonesia yang cenderung kolektivis.

Hasil yang menarik ditemukan pada korelasi antarvariabel yang menunjukkan bahwa keempat tipe achievement goal orientation memiliki korelasi yang signifikan antara satu sama lain. Menurut Elliot dan Murayama (2008), seharusnya hubungan antartipe achievement goal orientation hanya signifikan pada tipe dengan dimensi definisi yang sama, yaitu antara mastery-approach dan mastery-avoidance serta antara performance-approach dan performance-avoidance. Dengan adanya hubungan yang signifikan pada keempat tipe achievement goal orientation dalam penelitian ini menunjukkan adanya indikasi alat ukur AGQ-R kurang dapat mendiferensiasi tipe achievement goal orientation pada peserta didik jenjang 
pendidikan atas di Indonesia. Alasan lain yang mungkin mendasari hal ini adalah karena pada penelitian ini, peneliti mengukur tujuan belajar secara umum dan tidak spesifik pada tujuan belajar tertentu. Menurut Anderman dan Koenka (2017), achievement goal orientation akan lebih efektif ketika tujuan yang diukur lebih spesifik. Hal ini dapat menjadi pertimbangan bagi peneliti selanjutnya dalam mengukur tipe achievement goal orientation.

Hasil penelitian menunjukkan bahwa 31\% kecurangan akademik dapat dijelaskan dari keempat tipe achievement goal orientation dan norma subjektif secara bersama-sama, sementara $69 \%$ sisanya dijelaskan oleh variabel lain. Berdasarkan hal ini, masih perlu diketahui variabel-variabel lain yang juga turut memengaruhi kecurangan akademik pada peserta didik jenjang pendidikan menengah atas. Ketidakkonsistenan peranan tipe achievement goal orientation dalam memprediksi kecurangan akademik membuat adanya kemungkinan bahwa hubungan antara keduanya dimoderatori oleh variabel lain. Kemungkinan ini pernah dikemukakan dan dibuktikan oleh Daumiller dan Janke (2019), yang hasil penelitiannya menunjukkan bahwa dalam situasi dimana partisipan harus menampilkan kemampuannya, partisipan hanya akan melakukan kecurangan akademik ketika mereka menganggap lingkungannya mendukung kecurangan akademik. Hal ini berarti bahwa dalam penelitian Daumiller dan Janke (2019), norma subjektif memoderatori hubungan antara performance goal dan kecurangan akademik.

Peranan yang besar dari norma subjektif dibandingkan dengan tipe achievement goal orientation dalam memprediksi kecurangan akademik dapat menjadi pertimbangan dari pihak sekolah ketika membuat penanganan terkait kecurangan akademik yang dilakukan peserta didik jenjang pendidikan menengah atas selama melakukan BDR. Berdasarkan hal ini, dapat dilihat pula bahwa intervensi yang dilakukan tidak cukup hanya ditujukan pada individu-individu tertentu saja, melainkan perlu dilakukan secara sistemik agar terbentuk persepsi pada peserta didik bahwa teman-temannya tidak mendukung kecurangan akademik.

Pelaksanaan penelitian ini juga memiliki beberapa keterbatasan. Untuk penelitian dengan cakupan Indonesia, jumlah partisipan penelitian ini tergolong kecil. Hal ini terkait dengan terbatasnya waktu pengambilan data yang perlu dilakukan sebelum peserta didik tidak lagi belajar BDR secara penuh. Oleh karenanya, dalam melihat hasil penelitian, hal ini juga perlu menjadi pertimbangan. Dapat dilihat pula bahwa persebaran partisipan penelitian tidak merata dan lebih terkonsentrasi pada Pulau Jawa. Tidak meratanya persebaran partisipan berkaitan dengan metode sampling yang digunakan peneliti, yaitu convenience dan snowball sampling. Metode sampling tersebut membuat adanya kemungkinan bahwa pengumuman penelitian lebih banyak tersebar di daerah tertentu. Selain itu, adanya daerah yang sudah mulai melakukan pembelajaran kombinasi antara BDR dan tatap muka turut memengaruhi persebaran partisipan. Kemudian, walaupun alat ukur kecurangan akademik diketahui memiliki reliabilitas dan validitas yang baik dalam uji coba, alat ukur baru dimodifikasi dalam penelitian ini untuk menyesuaikan dengan pembelajaran BDR.

\section{SIMPULAN}

Penelitian ini bertujuan untuk melihat peran dari achievement goal orientation dan norma subjektif dalam memprediksi kecurangan akademik pada peserta didik jenjang pendidikan menengah atas selama BDR. Dapat disimpulkan bahwa hipotesis alternatif satu (Ha1) diterima, yang menunjukkan bahwa terdapat peran dari achievement goal orientation dan norma subjektif secara bersama-sama dalam memprediksi kecurangan akademik pada peserta didik jenjang pendidikan menengah atas selama melakukan BDR. Meskipun demikian, ketika dilihat lebih jauh lagi, dapat dilihat pula bahwa hipotesis alternatif 1.1 (Ha1.1), 1.2 (Ha1.2), 1.3 (Ha1.3), 1.4 (Ha1.4) ditolak. Hal ini menunjukkan bahwa peran masing-masing tipe achievement goal orientation dalam memprediksi kecurangan akademik tidak signifikan. Hipotesis alternatif 1.5 (Ha1.5) diterima, yang berarti bahwa norma subjektif memprediksi kecurangan akademik secara signifikan. Hal ini menunjukkan bahwa ketika seseorang memiliki persepsi bahwa lingkungannya membolehkan ia melakukan kecurangan akademik, maka ia akan cenderung melakukan kecurangan akademik. Berdasarkan hasil tersebut, dapat dilihat bahwa kecurangan akademik pada peserta didik jenjang pendidikan menengah atas lebih dipengaruhi oleh persepsinya terhadap pendapat teman terkait kecurangan akademik dibandingkan dengan tujuan berprestasinya. Pihak sekolah, psikolog sekolah, konselor, maupun guru, dapat menjadikan hasil penelitian ini sebagai pertimbangan dalam pembuatan intervensi untuk mengatasi dan mencegah kecurangan akademik pada peserta didik 
jenjang pendidikan atas selama BDR. Intervensi yang dilakukan yang dilakukan tidak cukup hanya bersifat individual saja, melainkan perlu dilakukan secara sistemik.

Adapun terkait dengan keterbatasan penelitian, terdapat beberapa saran metodologis yang dapat dipertimbangkan pada penelitian selanjutnya. Penelitian selanjutnya dapat menambah jumlah partisipan dengan persebaran karakteristik partisipan seperti asal daerah, jenis sekolah, dan kelas, yang lebih merata. Penelitian selanjutnya juga dapat mempertimbangkan untuk mengukur achievement goal orientation pada hal yang lebih spesifik dibandingkan dengan tujuan belajar secara umum agar tujuan belajar siswa dapat lebih terdiferensiasi. Berdasarkan hasil penelitian, diketahui bahwa $31 \%$ varians dari kecurangan akademik dapat diprediksi dari keempat tipe achievement goal orientation dan norma subjektif secara bersama-sama, sementara $69 \%$ sisanya dijelaskan oleh variabel lain. Oleh karena itu, peneliti selanjutnya dapat menambahkan variabel lain agar dapat diketahui lebih banyak faktor yang dapat memprediksi kecurangan akademik sehingga penanganan kecurangan akademik dapat dilakukan secara lebih komprehensif. Penelitian selanjutnya juga dapat mempertimbangkan adanya variabel moderator dalam melihat hubungan antara achievement goal orientation dan kecurangan akademik.

\section{DAFTAR PUSTAKA}

Anderman, E. M., \& Midgley, C. (2004). Changes in self-reported academic cheating across the transition from middle school to high school. Contemporary Educational Psychology, 29(4), 499 517. https://doi.org/10.1016/j.cedpsych.2004.02.002

Anderman, E. M., \& Koenka, A. C. (2017). The relation between academic motivation and cheating. Theory Into Practice, 56(2), 95-102. https://doi.org/10.1080/00405841.2017.1308172

Apostolou, M. (2015). Four personal achievement goals and self-reported cheating behavior. International Journal of School and Cognitive Psychology, 2(10), 1-7. doi: 10.4172/2469-9837.S2010

Bashir, H., \& Bala, R. (2018). Development and validation of academic dishonesty scale (ADS): Presenting a multidimensional scale. International Journal of Instruction, 11(2), 57-74. https://doi.org/10.12973/iji.2018.1125a

Blachnio, A. (2019). Don't cheat, be happy. Self-control, self-beliefs, and satisfaction with life in academic honesty: A cross-sectional study in Poland. Scandinavian Journal of Psychology. 60(3), 261-266. doi:10.1111/sjop.12534

Daumiller, M., \& Janke, S. (2019). Effects of performance goals and social norms on academic dishonesty in a test. British Journal of Educational Psychology, 90(2), 537-559. https://doi.org/10.1111/bjep.12310

Dendir, S., \& Maxwell, R. S. (2020). Cheating in online courses: Evidence from online $\begin{array}{llll}\text { proctoring. Computers in Human Behavior } & 100033 .\end{array}$ https://doi.org/10.1016/j.chbr.2020.100033

Diego, L. A. B. (2017). Friends with benefits: Causes and effects of learners' cheating practices during examination. IAFOR Journal of Education, 5(2) 121-138. https://doi.org/10.22492/ije.5.2.06

Elliot, A. J., \& McGregor, H. A. (2001). A $2 \times 2$ achievement goal framework. Journal of Personality and Social Psychology, 80(3), 501-519. https://doi.org/10.1037/0022-3514.80.3.501

Elliot, A. J., \& Murayama, K. (2008). On the measurement of achievement goals: Critique, illustration, and application. Journal of Educational Psychology, 100(3), 613-628. https://doi.org/10.1037/00220663.100 .3 .613

Field, A. (2013). Discovering statistics using IBM SPSS statistics (4th ed.). SAGE Publications. Greduasia. (2020). Tren Mencontek saat PJJ Meningkat, GREDU Ajak Guru, Konselor, dan Peneliti Berdiskusi. Kolom Gredu. Retrieved 13 February 2021, from https:/greduasia.wordpress.com/2020/10/26/tren-mencontek-saat-pjj-meningkat-gredu-ajak-gurukonselor-dan-peneliti-berdiskusi/.

Guerrero-Dib, J. G., Portales, L., \& Heredia-Escorza, Y. (2020). Impact of academic integrity on workplace ethical behaviour. International Journal for Educational Integrity, 16(2). https://doi.org/10.1007/s40979-020-0051-3 
Harding, T. S., Mayhew, M. J., Finelli, C. J., \& Carpenter, D. D. (2007). The theory of planned behavior as a model of academic dishonesty in engineering and humanities undergraduates. Ethics \& Behavior, 17(3), 255-279. doi:10.1080/10508420701519239

Huang, C. L., Yang, S. C., \& Chen, A. S. (2015). The relationships among students' achievement goals, willingness to report academic dishonesty, and engaging in academic dishonesty. Social Behavior and Personality: An International Journal, 43(1), 27-37. doi: 10.2224/sbp.2015.43.1.27

Imran, A. M., \& Nordin, M. S. (2013). Predicting the underlying factors of academic dishonesty among undergraduates in public universities: A path analysis approach. Journal of Academic Ethics, 11(2), 103-120. doi: 10.1007/s10805-013-9183-x

Ives, B., \& Giukin, L. (2019). Patterns and predictors of academic dishonesty in Moldovan University students. Journal of Academic Ethics, 18(1), 71-88. https://doi.org/10.1007/s10805-019-09347-z

Jensen, L. A., Arnett, J. J., Feldman, S. S., \& Cauffman, E. (2002). It's wrong, but everybody does it: Academic dishonesty among high school and college students. Contemporary Educational Psychology, 27(2), 209-228. doi:10.1006/ceps.2001.1088

Kam, C. C. S., Hue, M. T., \& Cheung, H. Y. (2018). Academic dishonesty among Hong Kong secondary school students: Application of theory of planned behaviour. Educational Psychology, 38(7), 945963. doi: $10.1080 / 01443410.2018 .1454588$

Kaufman, H. E. (2008). Moral and ethical issues related to academic dishonesty on college campuses. Journal of College and Character, 9(5), 1-8. doi: 10.2202/1940-1639.1187

Kementerian Pendidikan dan Kebudayaan. Surat Edaran No. 4 Tahun 2020 Tentang Pelaksanaan Kebijakan Pendidikan Dalam Masa Darurat Penyebaran Coronavirus Disease (COVID-19) (2020). Jakarta.

Krou, M. R., Fong, C. J., \& Hoff, M. A. (2020). Achievement motivation and academic dishonesty: A meta-analytic investigation. Educational Psychology Review, 33(2), 427-458. https://doi.org/10.1007/s10648-020-09557-7

Lonsdale, D. (2016). Intentions to cheat: Ajzen's planned behavior and goal-related personality facets. The Journal of Psychology, 151(2), 113-129. doi:10.1080/00223980.2016.1241737

Maloshonok, N., \& Shmeleva, E. (2019). Factors influencing academic dishonesty among undergraduate students at Russian universities. Journal of Academic Ethics, 17(3), 313-329. https://doi.org/10.1007/s10805-019-9324-y

McCabe, D. L., Butterfield, K. D., \& Treviño, L. K. (2012). Cheating in College: Why Students Do It and What Educators Can Do About It. Baltimore: The Johns Hopkins University Press.

Munoz, A., \& Mackay, J. (2019). An online testing design choice typology towards cheating threat minimisation. Journal of University Teaching \& Learning Practice, 16(3).

Mustafa, S. (2020). Belajar dari Rumah melalui Pembelajaran Jarak Jauh di SMA. Jakarta: Kementerian Pendidikan dan Kebudayaan.

Neighbors, C., Foster, D. W., \& Fossos, N. (2013). Peer influences on addiction. In P. Miller, Principles of Addiction: Comprehensive Addictive Behaviours and Disorders. Elsevier.

Papalia, D. E., \& Martorell, G. (2014). Experience Human Development (13th ed.). New York: McGraw Hill Education.

Peled, Y., Eshet, Y., Barczyk, C., \& Grinautski, K. (2019). Predictors of academic dishonesty among undergraduate students in online and face-to-face courses. Computers \& Education, 131, 49-59. https://doi.org/10.1016/j.compedu.2018.05.012

Pintrich, P. R. (2000). An achievement goal theory perspective on issues in motivation terminology, theory, and research. Contemporary Educational Psychology, 25(1), 92-104. doi: 10.1006/ceps.1999.1017

Rodliya, R. (2018). Reliabilitas dan validitas konstruk achievement goal questionnaire - revised (AGQR) versi Indonesia. Skripsi. Universitas Pendidikan Indonesia.

Shmeleva, E., \& Semenova, T. (2019). Academic dishonesty among college students: Academic motivation vs contextual factors. Voprosy Obrazovaniya / Educational Studies Moscow, (3), 101129. https://doi.org/10.17323/1814-9545-2019-3-101-129 
Ursachi, G., Horodnic, I. A., \& Zait, A. (2015). How reliable are measurement scales? External factors with indirect influence on reliability estimators. Procedia Economics and Finance, 20, 679-686. https://doi.org/10.1016/s2212-5671(15)00123-9

Van Yperen, N. W., Hamstra, M. R. W., \& van der Klauw, M. (2011). To win, or not to lose, at any cost: The impact of achievement goals on cheating. British Journal of Management, 22(s1), S5-S15. doi:10.1111/j.1467-8551.2010.00702.x

Yang, S. C., Huang, C. L., \& Chen, A. S. (2013). An investigation of college students' perceptions of academic dishonesty, reasons for dishonesty, achievement goals, and willingness to report dishonest behavior. Ethics \& Behavior, 23(6), 501-522. doi: 10.1080/10508422.2013.802651

Yu, H., Glanzer, P. L., Sriram, R., Johnson, B. R., \& Moore, B. (2016). What contributes to college students' cheating? A study of individual factors. Ethics \& Behavior, 27(5), 401-422. https://doi.org/10.1080/10508422.2016.1169535 